\title{
TP53 R72P polymorphism modulates DNA methylation in hepatocellular carcinoma
}

\author{
Khadija Rebbani ${ }^{1,2 \dagger}$, Agnès Marchio ${ }^{1 \dagger}$, Sayeh Ezzikouri ${ }^{2}$, Rajaa Afifi ${ }^{3}$, Mostafa Kandii ${ }^{4}$, Olfa Bahri ${ }^{5}$, Henda Triki ${ }^{5}$, \\ Abdellah Essaid El Feydi ${ }^{3}$, Anne Dejean ${ }^{1}$, Soumaya Benjelloun ${ }^{2}$ and Pascal Pineau ${ }^{1 *}$
}

\begin{abstract}
Background: Hepatocellular carcinoma (HCC) is characterized by widespread epidemiological and molecular heterogeneity. Previous work showed that in the western part of North Africa, a region of low incidence of HCC, mutations are scarce for this tumor type. As epigenetic changes are considered possible surrogates to mutations in human cancers, we decided, thus, to characterize DNA methylation in HCC from North-African patients.

Methods: A set of 11 loci was investigated in a series of 45 tumor specimens using methylation-specific and combined-bisulfite restriction assay PCR. Results obtained on clinical samples were subsequently validated in liver cancer cell lines.

Results: DNA methylation at tumor suppressor loci is significantly higher in samples displaying chromosome instability. More importantly, DNA methylation was significantly higher in Arg/Arg when compared to Pro/Pro genotype carriers at codon 72 rs 1042522 of TP53 (65\% vs 20\% methylated loci, $p=0.0006$ ), a polymorphism already known to affect somatic mutation rate in human carcinomas. In vitro experiments in cell lines indicated that enzymes controlling DNA methylation were differentially regulated by codon 72 Arg or Pro isoforms of p53. Furthermore, the Arg72-carrying version of p53 was shown to re-methylate DNA more rapidly than the pro-harboring isoform. Finally, Pro-carrying cell lines were shown to be significantly more resistant to decitabine treatment (two-fold, $p=0.005$ ).

Conclusions: Our data suggest that Arg72Pro polymorphism in a WT p53 context may act as a primary driver of epigenetic changes in HCC. It suggests, in addition, that rs1042522 genotype may predict sensitivity to epigenetictargeted therapy. This model of liver tumorigenesis that associates low penetrance genetic predisposition to epigenetic changes emerges from a region of low HCC incidence and it may, therefore, apply essentially to population living in similar areas. Surveys on populations submitted to highly mutagenic conditions as perinatally-acquired chronic hepatitis B or aflatoxin B1 exposure remained to be conducted to validate our observations as a general model.
\end{abstract}

Keywords: TP53, DNA methylation, Hepatocellular Carcinoma, Polymorphism

\section{Background}

Hepatocellular carcinoma (HCC), the most frequent primary liver tumor, is a malignancy affecting around $710^{5}$ patients each year, with highest incidences measured in Sub-Saharan Africa and Eastern Asia. HCC is now the fifth most common malignant tumor and the third common cause of cancer-related mortality worldwide [1]. The Western North-Africa (WNA: Morocco, Algeria and Tunisia), is considered as an area of intermediate

\footnotetext{
* Correspondence: pascal.pineau@pasteur.fr

'Equal contributors

'Unité d'Organisation Nucléaire et Oncogenèse, INSERM U993, Institut

Pasteur, 28 rue du Docteur Roux, F-75724 Paris, Cedex 15, France

Full list of author information is available at the end of the article
}

endemicities for chronic viral hepatitis B and C, and displays much lower incidences of HCC than both European or African neighboring countries [2,3]. It is generally admitted that liver tumorigenesis is a consequence of accumulation of genetic and epigenetic alterations in key genes controlling proapoptotic or prosurvival signals. These changes occur generally in an impaired hepatic tissue undergoing a persistent viral infection and/or a cirrhosis, but it could be promoted also by an exposure to mutagens such as aflatoxin B1 [4]. Several classifications of HCC were established to differentiate tumors by focusing on histological characteristics, gene mutations in TP53 and Wnt pathways and hypermethylation of tumor suppressor 
genes (TSG) $[5,6]$. In addition, HCC can be genomically characterized from the most instable tumors with frequent TP53 and AXIN1 mutations to stable tumors with $\beta$-catenin alterations [7]. Moreover, transcriptomics revealed an overexpression of imprinted and mitotic cell cycle genes within instable tumors at odds with stable ones that show increased levels of metabolism-controlling genes coupled to an underexpression of stress, immune response and cell adhesion coding genes [8,9]. Epigenetic alterations, and particularly DNA methylation, are also suspected to represent a class of decisive events in liver tumorigenesis. Indeed, diverse studies have been carried out on different cohorts of HCC patients affording insight about epigenetic changes controlling liver carcinogenesis [10]. Hypermethylation of a set of TSG such as RASSF1, RIZ, CDK2NA and GSTP1 is commonly reported in HCC [11]. Such targeted silencing is generally accompanied by a global hypomethylation affecting repetitive elements covering the genome $[12,13]$. The connections between genetic and epigenetic features mentioned above are still poorly understood. Finally, numerous studies have been performed to explore the association of the genetic background of patients with an eventual individual susceptibility to HCC $[14,15]$. TP53 presents, at codon 72 , a functional single nucleotide polymorphism (SNP, R72P, rs1042522) that modulates the susceptibility to several cancers including HCC [16]. Notably, the presence of an arginine at codon 72 is known to be associated with higher rates of somatic TP53 mutations in tumors [17].

Despite this apparent wealth of data, carcinogenesis in specific populations such as WNA inhabitants is still poorly understood. The WNA patients are, actually, characterized by the scarcity of alterations found in HCC [2]. This situation suggests that epigenetic changes may be the most significant changes in WNA patients. The aim of the study was, thus, to provide an appraisal of the epigenetic changes occurring in HCC from a WNA population. Methylation status at 10 individual loci as well as at repetitive elements (LINE-1) was assessed. Variations in DNA methylation levels were further confronted with genetic data including $\beta$-catenin and TP53 mutations, chromosomal instability (CIN) and genotypes of selected SNPs. We found that, in HCC from WNA, somatic changes including methylation, mutations, or CIN were primarily conditioned by the genotype at codon 72 of TP53. The current report represents the first description of the existing correlation between TP53 R72P and epigenetic changes in tumors.

\section{Results}

Tumor specific patterns in HCC compared with the corresponding non-tumorous tissues

Clinico-biological features of the HCC patients are summarized in Table 1. In this study, we examined methylation
Table 1 Characteristics of the $\mathbf{4 5}$ patients analyzed

\begin{tabular}{llll}
\hline ClinicoBiological features & & $\mathbf{n}$ & \% \\
\hline Gender & Women & 12 & 26.7 \\
Age & men & 33 & 73.3 \\
& median \pm SD & $58.6 \pm 11.6$ & \\
Risk factors & range & $28-79$ & \\
& anti-HCV & 26 & 58 \\
& HBs Ag & 10 & 22 \\
Cirrhotic liver & anti-HBC & 20 & 44 \\
Tumor diameter & & 38 & 84 \\
& mean \pm SD & $5.1 \pm 3.6$ & \\
Point mutations & median & 4 & \\
& range & $1-13$ & \\
& TP53 & 9 & 20 \\
& B-catenin & 4 & 0 \\
Chromosome instability & AXIN1 & 0 & \\
& mean \pm SD & $29 \pm 24$ & \\
& median & 20 & \\
& range & $0-80$ & \\
\hline
\end{tabular}

Chromosome instability is expressed as the fraction of chromosome arms lost in a given samples (chromosomes 1p, 4q, 6q, 8p, 9p, 17p were analyzed). $\mathrm{HCV}$, hepatitis $C$ virus; $\mathrm{HBs} A g$, surface antigen of hepatitis $B$ virus; $\mathrm{HBC}$, hepatitis B virus capsid/core.

patterns of ten tumor-associated genes (RASSF1A, GSTP1, RIZ1, SOCS1, TNFRSF10C, hTERT, NRG1, CLU, miR-203, miR-663) and of the LINE-1 repetitive element in 45 HCC and 17 matching non-tumor livers (see Figure 1 and Additional file 1: Table S1). Genes were selected on the basis of the literature as aberrantly methylated in different human cancers including HCC [18-29].We define Methylation Index (MethIndex) as the number of methylated genes on the total number of informative loci analyzed for a given sample (LINE-1 was excluded from the calculation as it is constitutively methylated). miR-663 was found unmethylated in all samples.

First, we intended to check whether there was a significant increase of DNA methylation in tumors when compared with non-tumorous DNA extracted from the liver tissue of patients with HCC. The methylation profiles of 17 HCCs and their matching non-tumorous liver (NTL) tissues were visualized on a heatmap produced by unsupervised hierarchical clustering approach. Major differences between tumors and non-tumorous DNA enabled clustering analysis to discriminate between sample types (see Figure 2A). Significant differences or trends between HCC and NTL were detectable at four loci (SOCS1, RIZ1, TNFRSF10C, miR-203) out of the $11 \mathrm{ex}-$ amined (Figure 2B). RASSF1 locus comparison displayed only an infra-significant $\mathrm{P}$ value $(\mathrm{P}=0.083)$. The overall difference between malignant and non-malignant tissues 


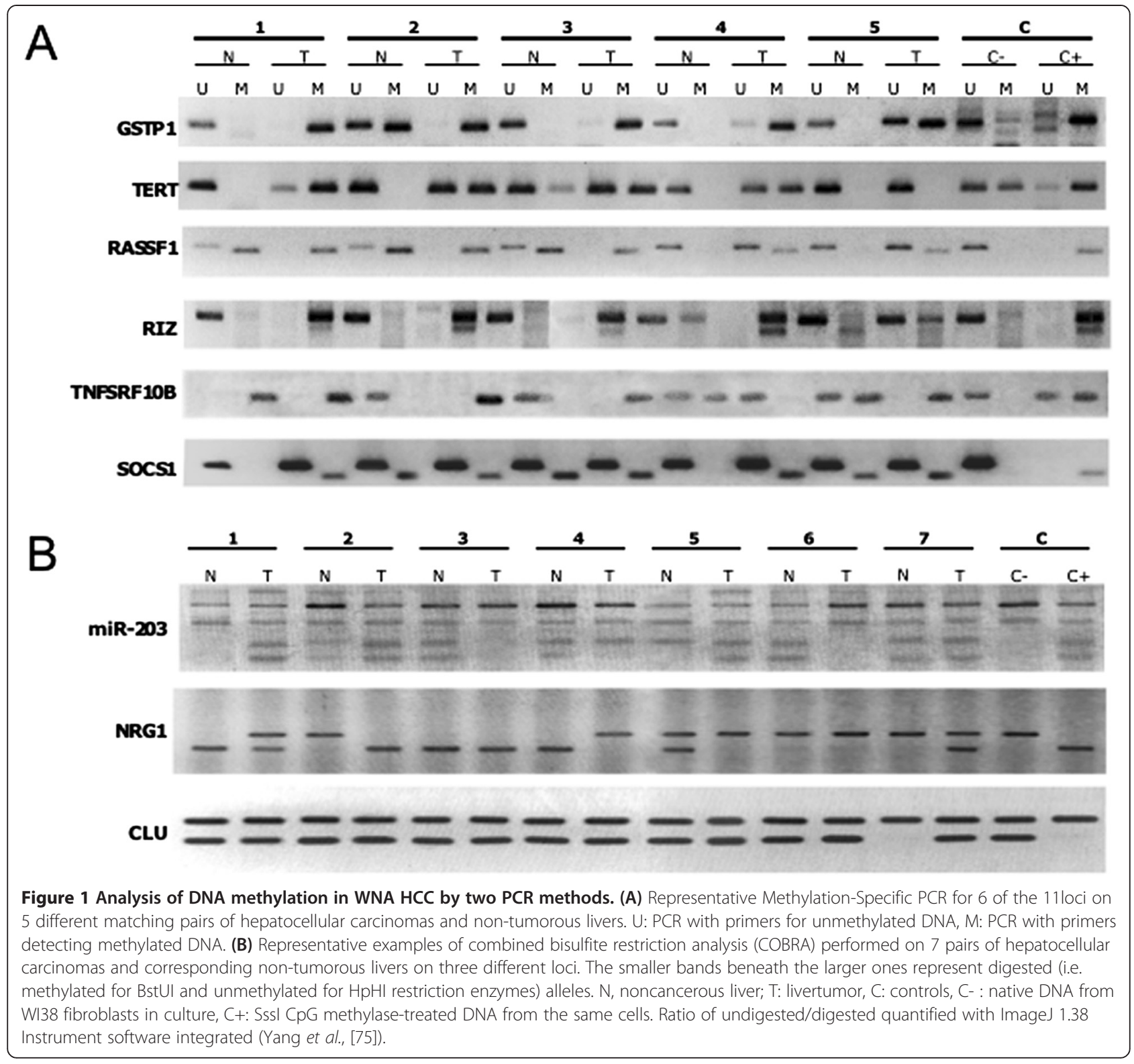

was highly significant (MethIndex was mean $\pm \mathrm{SD}=44 \pm$ $20 \%$ in HCC versus $24 \pm 20 \%$ in NT, p $=0.003$, Figure $2 C$ ).

\section{Patterns of DNA methylation in HCC from WNA}

We then wondered whether the methylation pattern could distinguish different subsets of tumors in correlation with previously analyzed somatic mutations, loss of heterozygosity (LOH) or SNPs $[2,30]$. Unsupervised hierarchical clustering distinguished three categories of HCC patients: those with low MethIndex (mean $\pm \mathrm{SD}=$ $19 \pm 18 \%)$, a second group with medium MethIndex $(42 \pm 12 \%)$ and a third subset with high $(69 \pm 11 \%)$ MethIndex (Figure 3A). TP53 somatic mutations and $\mathrm{LOH}$ at chromosome 17p (TP53 maps in 17p13.1) were significantly associated with the high methylation index cluster $(p=0.022$ and $p=0.014)$. Single-locus matrix of correlation revealed frequent significant associations between methylation occurring at RIZ1 or RASSF1 promoters and presence of methylation at other loci (Additional file 1: Table S2). Furthermore, increased methylation of tumor suppressor genes or decreased methylation of LINE-1 repetitive element, were associated with higher rates of somatic changes in tumor samples. There was a strong correlation between LINE-1 demethylation and the loss of chromosome 17p or the presence of somatic mutations in the tumor (either at TP53 or CTNNB1, $\mathrm{p}=0.006$, see Figure 3B). We next decided to explore whether DNA methylation at individual loci could be correlated with a more general form of chromosome instability. We calculated in a previous work on the same 


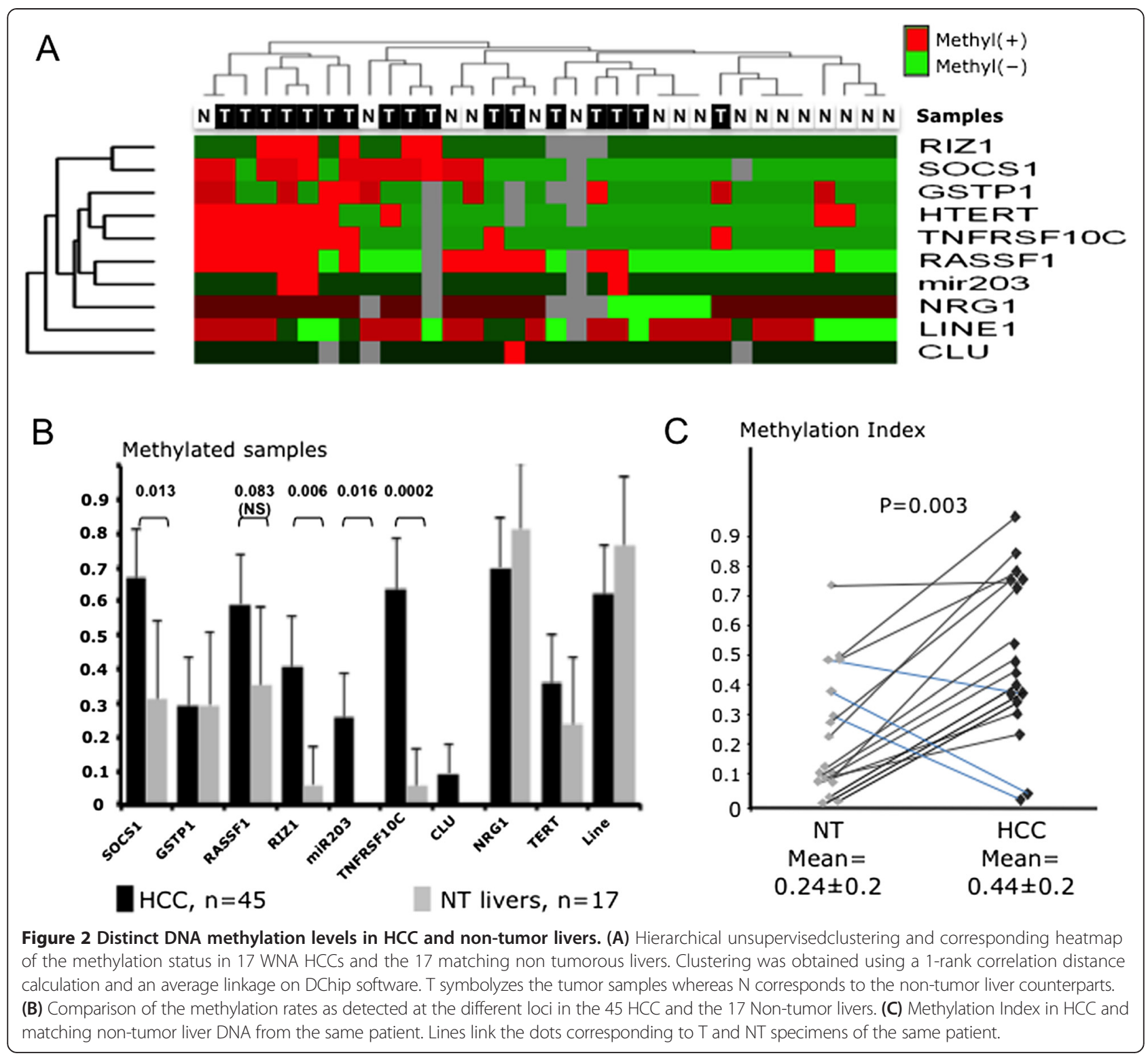

samples the fractional allelic loss (FAL) for common deletion targets in HCC (1p, 4q, 6q, 8p, 9p and 17p) [2]. FAL is the number of chromosome arms showing $\mathrm{LOH} / \mathrm{num}$ ber of informative chromosome in a given sample [31,32]. RASSF1 methylated status was significantly associated with higher FAL values $(\mathrm{p}=0.034$, Figure $3 \mathrm{C})$ as well as isolated 17p loss (Additional file 1: Table S3). Methylation of RIZ1 and miR-203 was positively correlated with somatic mutations or losses at chromosome $17 \mathrm{p}$ and $4 \mathrm{q}$ (see Additional file 1: Table S3). Finally, we noticed a strong influence of the SNP rs1042522 on the methylation of WNA HCCs. The proline variant at codon 72 of TP53 gene was significantly associated with the low methylation cluster $(\mathrm{p}=0.04$, Figure $3 \mathrm{~A})$, and specifically with an almost complete absence of methylation on RIZ1, TNFRSF10C, NRG1, hTERT and miR-203. When the
MethIndex was stratified according to TP53 codon 72 genotypes, significant differences were even more apparent (see Figure 3D). A very low MethIndex was associated with Pro/Pro genotype (mean $\pm \mathrm{SD}=20.8 \pm 14 \%$ ) whereas methylation was significantly higher in tumors of individuals homozygous for arginine $(57.1 \pm 19 \%, \mathrm{P}=0.0006)$. Tumors from heterozygous Arg/Pro were occupying an intermediate position for MethIndex (39.1 $\pm 23 \%)$ suggesting the existence of an allele dosage effect of TP53 codon 72 polymorphism on the DNA methylation in HCC from WNA patients. In addition, MethIndex distributions for Arg/Arg and Arg/Pro carriers were displaying a bimodal distribution (see Figure 3D). Methylation of SOCS1 was appearing as particularly correlated with TP53 codon 72 genotype (see Additional file 1: Table S3). 


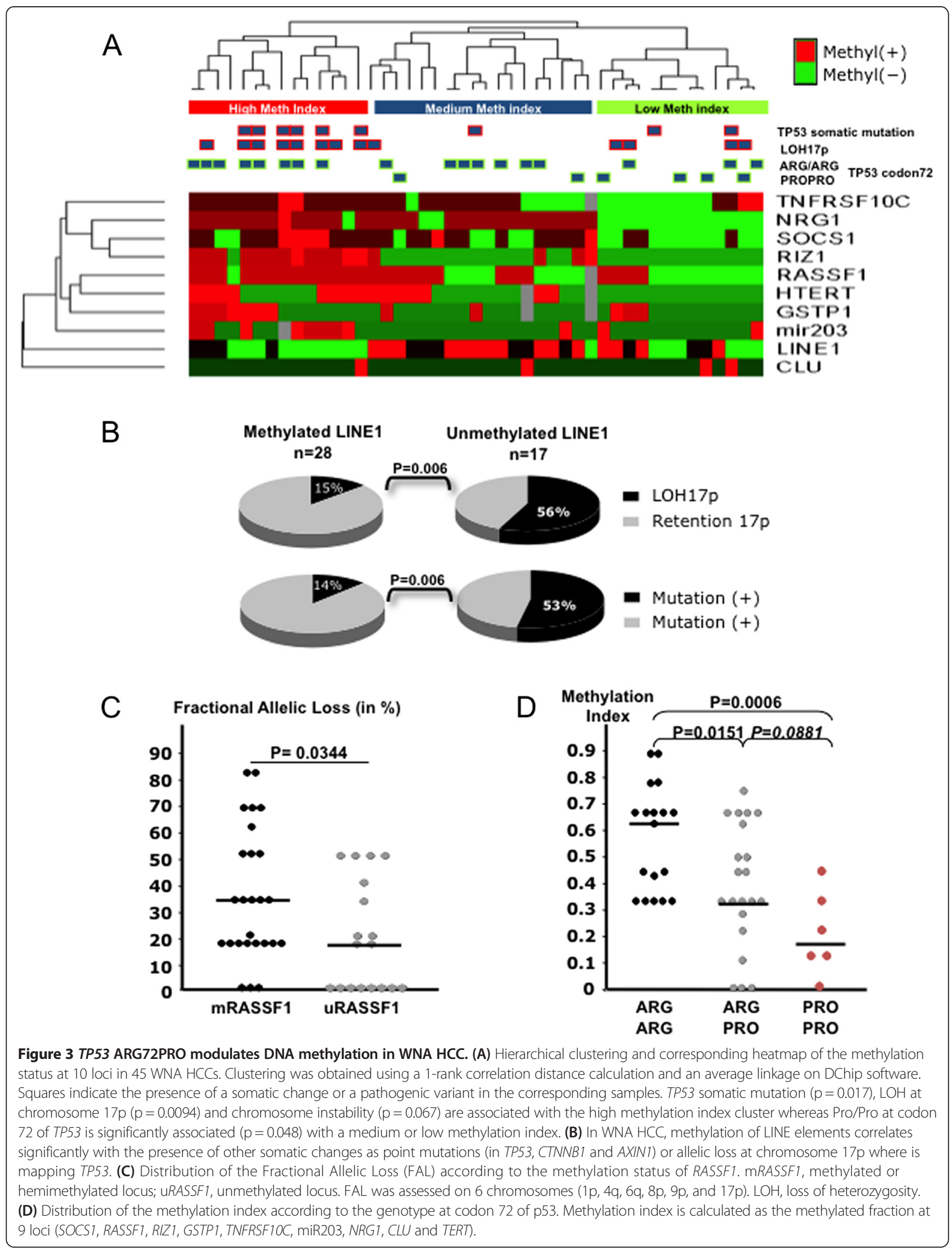




\section{DNA methylation in peripheral blood mononuclear cells (PBMCs) of HCC patients and controls}

Predicting the propensity of individuals to undergo a strong DNA methylation in their tumors may prove to be useful in a perspective of future treatment by epigenetic-targeting drugs. To determine whether it is possible to find a correlation between the aberrant methylation process ongoing in tumors and the DNA methylation in circulating lymphocytes, we analyzed the DNA extracted from peripheral lymphocytes of 25 patients with $\mathrm{HCC}$ and 35 patients with chronic hepatitis B or $\mathrm{C}$ but without HCC. All patients were from WNA. No significant differences were detected between patients with or without primary liver cancer (see Additional file 2: Figure S1A). DNA Methylation was very low in PBMCs of HCC patients as well as in patients infected by hepatitis viruses (Additional file 2: Figure S1B). In contrast, LINE-1 methylation remained high in both subsets of samples. Genetic targets usually used to assess the methylation process in tumors did not appear to be sensitive markers reflecting the tumor DNA methylation level when they were analyzed ectopically as in PBMC (Additional file 2: Figure S1C).

\section{DNMT and DNA demethylases expression levels in liver cancer cell lines according to TP53 codon72 genotype}

We decided subsequently to explore in vitro whether p53 codon 72 Arg or Pro-encoding isoforms could be endowed of a differential transcriptional activity, explaining the rate of DNA methylation observed in vivo. For this purpose, we analyzed eight different TP53 wild-type HCC cell lines differing at codon 72 (Figure 4A). All these cell lines were expressing p53 protein either at baseline or upon induction by doxorubicin $(0.2 \mu \mathrm{M} /$ 24 h, see western-blot on Figure 4B).

TP53 encodes a transcription activator/repressor known to modulate directly or indirectly expression levels of many genes [33]. As the codon 72 Arg72Pro polymorphism is located in the transactivation domain of the protein, we wondered whether this genetic variation might impact the capacity of p53 to modulate expression of those genes most directly involved in DNA methylation i.e. DNA methyltransferases and demethylases $[34,35]$. Using qPCR, we compared the expression of sixteen genes encoding for factors modulating DNA methylation levels positively or negatively. Gene expression was measured after $0.5 \mu \mathrm{M}$ doxorubicin, or $2.5 \mu \mathrm{M}$ decitabine or vehicle treatment for $48 \mathrm{~h}$. Baseline or post-decitabine expression of the 16 genes was not different according to TP53 codon 72 genotypes (data not shown). Following doxorubicin treatment, we did not observe difference for two bona fide p53-responsive genes (p21-CDKN1A, GADD45). By contrast, DNMT3A, TET1 and TET2 expression levels were significantly higher in
Arg/Arg cell lines whereas in a Pro/Pro background APO$B E C 3 B$ expression was increased (see Figure $4 C$ ). Importantly, TP53 expression was significantly higher in Pro/Pro cells. These data suggest that, in case of genotoxic stress, Arg-bearing isoforms of p53 are more efficient inducers of enzyme controlling DNA methylation than Pro-encoding isoforms.

\section{Impact of TP53 codon 72 Arg/Pro on DNA methylation levels}

We next explored whether it is possible to mimic in cell lines what we observed on DNA from North-African HCC patients i.e. an increased DNA methylation in presence of Arg/Arg genotype. At variance with commonly performed gene inactivation experiments, differences of activity between two natural variants of a fully functional protein were predictably rather mild [36]. Furthermore, the DNA methylation status is intrinsic to each cell line and may differ widely at baseline. We thus decided to analyze DNA methylation and re-methylation dynamics following treatment with drugs modifying DNA methylation levels. Decitabine alone, doxorubicin alone or both drugs were sequentially used. Doxorubicin, as an intercalating agent, is known to induce DNA breaks but early reports have shown as well its capacity to induce DNA methylation [32]. To analyze methylation variations, we used a methylation-specific restriction enzyme (MSRE)-coupled qPCR method [37,38]. A set of seven CpG island-containing promoters (BIRC5, CDC25C, CLU, GSTP1, NRG1, RASSF1, SOCS1) was investigated on the panel of TP53 wild-type codon $72 \mathrm{Arg}$ or Pro HCC cell lines (Additional file 3: Figure S2).

The impact of the treatment was dependent on the compound and on the promoter analyzed. No difference in DNA methylation level was observed after doxorubicin or decitabine treatment alone (data not shown). However, when decitabine $(5 \mu \mathrm{M} / 72 \mathrm{~h})$ and doxorubicin $(0.25 \mu \mathrm{M} / 24 \mathrm{~h})$ were used sequentially in a demethylationremethylation procedure, a frequently higher rate of DNA methylation was observed (see Figure 5A) in presence of codon 72 Arg forms of p53, indicating a more active kinetic of DNA methylation. The phenomenon was particularly pronounced for genes displaying differential methylation in vivo (GSTP1, NRG1, RASSF1, and SOCS1). It was not observed on promoters of genes without differential methylation $(C L U)$ or controlling cell cycle (data of CDC25C, BIRC5 are not shown).

\section{TP53 codon 72 polymorphism affects sensitivity to treatment}

Given the differential gene expression or DNA methylation capacity of p53 variants, the issue of a differential sensitivity to epigenetic-targeted treatment was asked. The eight TP53 WT cell lines were, thus, treated either 


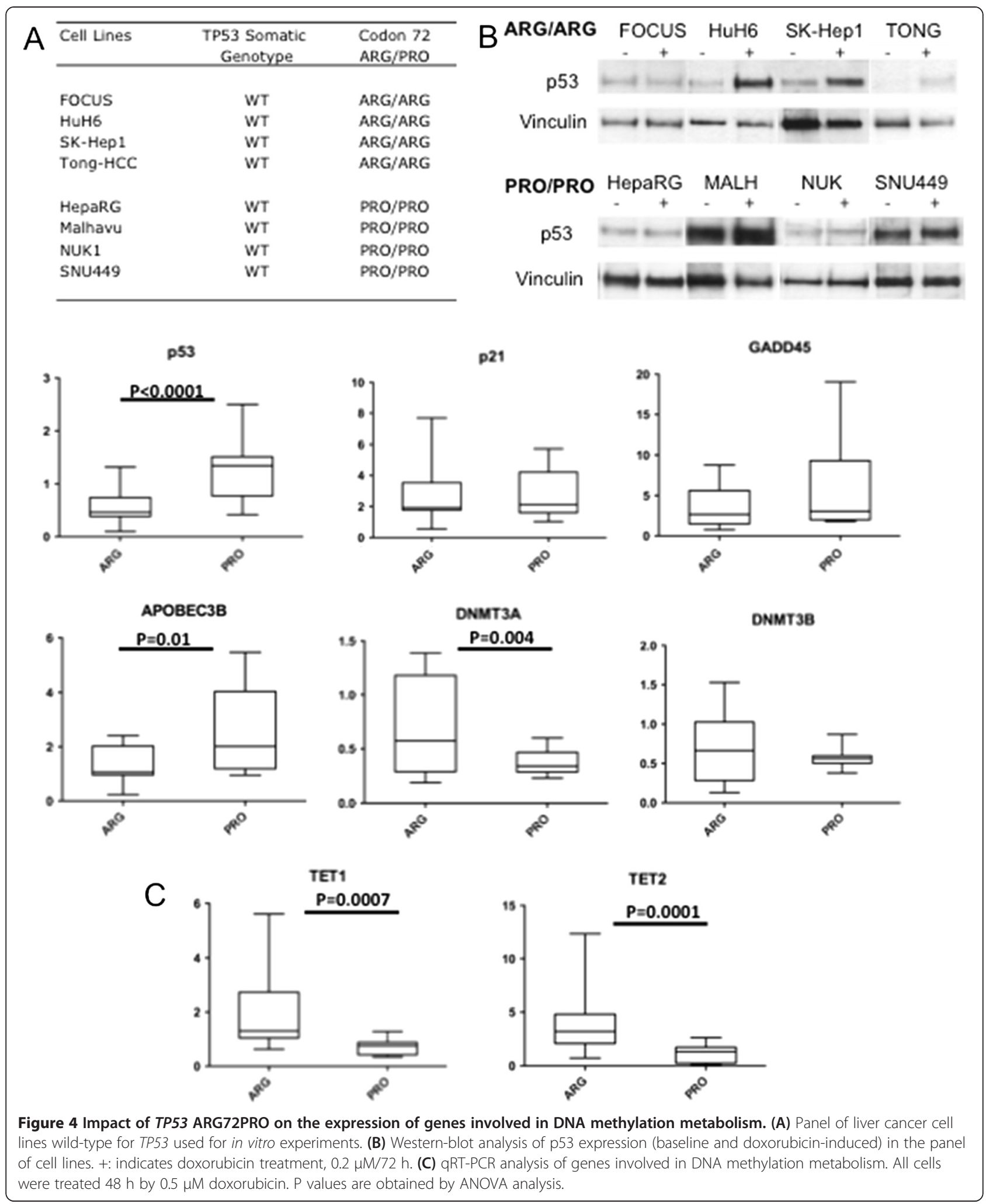




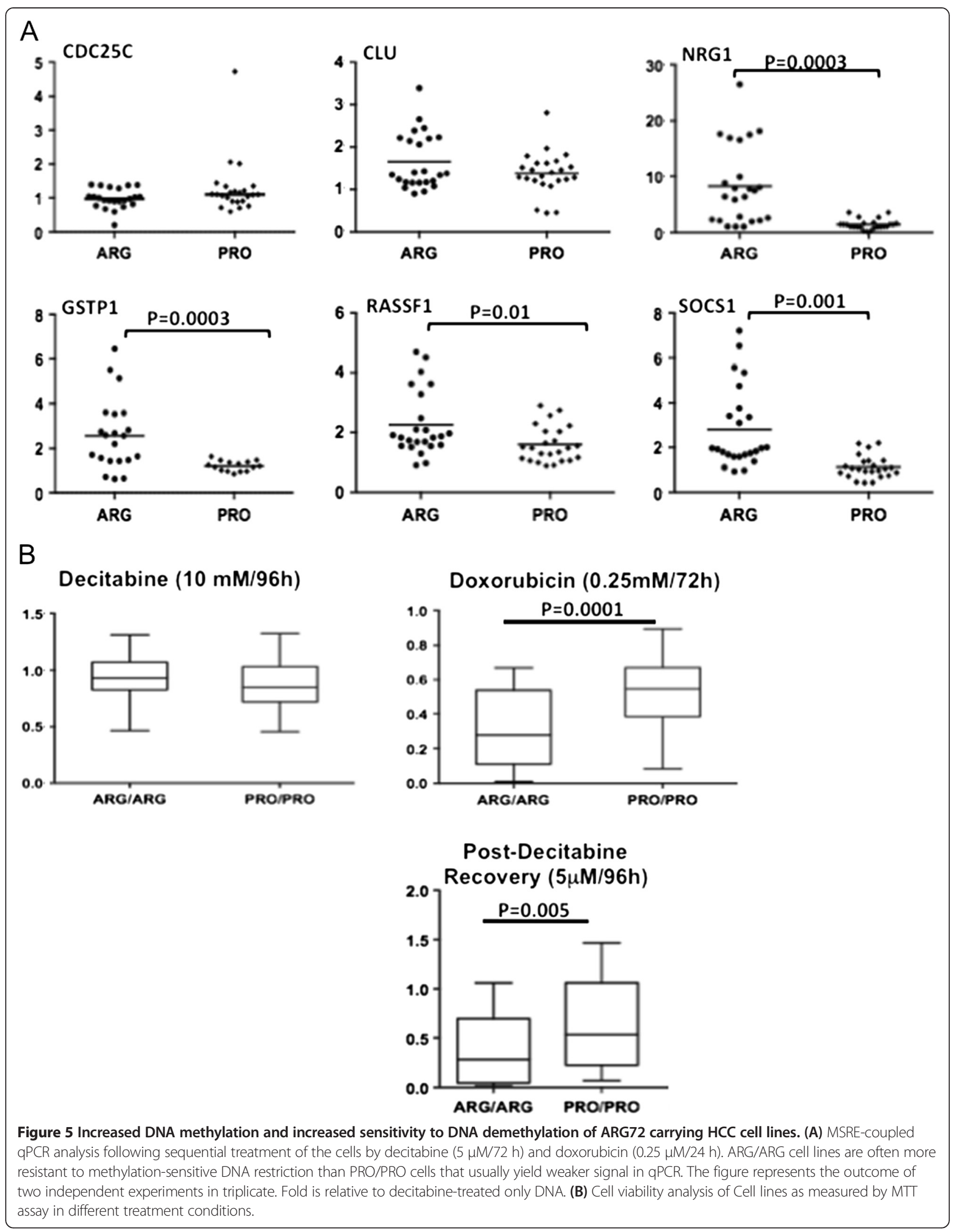


with decitabine $(10 \mu \mathrm{M} / 96 \mathrm{~h})$ or doxorubicin $(0.25 \mu \mathrm{M} /$ $72 \mathrm{~h}$ ) and cell viability measured by MTT assay. No difference was observed with decitabine whereas homozygous Arg cells were significantly more sensitive to doxorubicin treatment (Figure 5B). Previous experiments have shown that differential in vitro effect of codon 72 polymorphism was essentially a kinetic-dependent phenomenon rather than relying on a difference in nature. We thus decided to measure the effect of decitabine at different time point after removal of the active compound. Cells were treated by $5 \mu \mathrm{M}$ decitabine during $96 \mathrm{~h}$ and cell culture medium was then replaced by decitabine-free medium. Cell viability was then measured at $24 \mathrm{~h}, 48 \mathrm{~h}, 72 \mathrm{~h}, 96 \mathrm{~h}, 7$ days and 10 days. No difference was observed after $24 \mathrm{~h}$ or 7 and 10 days of recovery (data not shown). However, significant differences of cell viability were observed $48 \mathrm{~h}(\mathrm{p}=0.05$, not shown), $72 \mathrm{~h}(\mathrm{p}=0.01$, not shown), and $96 \mathrm{~h}(\mathrm{p}=$ 0.005 , see Figure $5 \mathrm{~B}$ ) post-decitabine removal. In these settings, Arg/Arg $\mathrm{HCC}$ cells were significantly less viable than Pro/Pro. These results suggest, therefore, a more efficient death-inducing activity of decitabine in an Argbearing p53 background.

\section{Discussion}

HCC epidemiology is known to follow ethno-geographic variations of incidence. Intriguingly, despite intermediate endemicities for chronic viral hepatitis $\mathrm{B}$ and $\mathrm{C}$, low incidences of HCC are registered in the WNA populations (1.2-2.3 cases $/ 10^{5}$ habitants for males, age standardized ratio, http://globocan.iarc.fr/) [39,40]. Remarkably, in WNA, HCC is characterized by a relative paucity of mutations at common genetic targets (TP53, CTNNB1, AXIN1), making of liver tumorigenesis in WNA a rather mysterious process (2). Nevertheless, and despite an apparently mild tumor process, HCC prognosis in WNA is as bad as anywhere else [41,42].

To date, no survey characterizing epigenetic features of HCC in WNA patients has been published. Our results were in accordance with those published by Hernandez-Vargas et al. underlining the importance of aberrant methylation that differentially affects RASSF1, RIZ1 and SOCS1 in tumors and non-tumorous tissues [43]. A rather high level of methylation was observed in four NT liver DNA ( $\geq 4$ loci methyl( + ), see Figure $2 \mathrm{~A})$. We could not find any annotations common to the four patients. However, we observed that their non-tumor liver tissues tended to be more frequently non cirrhotic ( $3 / 4$ vs $5 / 41, \mathrm{p}=0.014)$ and the FAL in tumors slightly higher (38 vs $28 \%$, ns) than in other samples of the series. These observations might indicate that a stronger carcinogenic process conferring a preneoplastic status to NT liver is at work in these patients. Alternatively, it might be the consequence of a field cancerization process in absence of full-fledged cirrhosis [44-46].
Besides, Nishida et al. have shown that DNA methylation levels are correlated with chromosomal instability, TP53 and $\beta$-catenin mutations [47]. Our data broadly corroborated this model, though without integrating $\beta$ catenin, as this alteration is very infrequent in WNA HCC. We hereby presented data refining and strengthening this model by showing a link between polymorphism at codon 72 of TP53, somatic mutations, chromosomal instability and DNA methylation status in HCC from WNA patients. The preferential association of codon 72 Arg with somatic mutation of TP53 has been thoroughly reviewed by Soussi and Wiman [17]. Likewise, the wellknown association of chromosomal instability and TP53 mutation will preferentially occur in an Arg/Arg context [48]. Finally, it has been shown that DNA methylation is significantly reduced in Li-Fraumeni cell lines [49]. However, to our best knowledge, a correlation between aberrant methylation and germline background of patients for TP53 was never reported.

The TP53 R72P polymorphism is known to be functionally relevant. The Arg variant was shown to be associated with a better apoptotic activity compared to Pro allele [50]. Furthermore, predisposition studies showed that the presence of the Pro allele is commonly associated with a higher risk of cancer including HCC [30,51] and of defects in embryonic implantation [52]. Our data indicate that codon 72 polymorphism conditions, apparently, genomic and epigenetic alterations encountered in the tumor tissue. In the current series of HCC from WNA patients, the Pro variant is associated with paucimutated and mildly methylated tumors. On the contrary, the presence of Arg allele requires the presence of additional somatic mutations and frequent DNA hypermethylation. It is well known that aging process is accompanied by an increase of genomic methylation that progressively decreases the expression of multiple genes [53]. Moreover, as shown in mouse models, an excess of p53 activity is characterized by an aging-like syndrome [54]. Finally, it has been shown in humans that TP53 codon72 Pro carriers tend to live longer than Arg carriers [55]. A link between rs1042522 and constitutive DNA methylation was, however, never evoked so far. Our results indicated consistently that TP53 codon72 Arg/Pro polymorphism may, in the North-African ethno-environmental settings, influence somatic evolution through the modulation of DNA methylation levels. The fact that we were able to reproduce this situation in vitro reinforces this hypothesis. We did not detect baseline differences of DNA methylation between cell lines but an increased DNA methylation was often detectable in Arg/Arg cells after decitabine-induced demethylation and subsequent doxorubicin-induced DNA re-methylation. Interestingly, three of the genes showing differential methylation between Arg and Pro variants (GSTP1, RASSF1, and SOCS1) are known to be p53 
targets [56-58]. This situation suggests that p53 may, depending on circumstances activates or methylate its target genes. The system we developed in vitro is relatively removed from physiological conditions or from a slow and long lasting process as tumorigenesis but it suggests that p53 controls DNA-methylation plasticity in condition of stress. Genome wide DNA methylation studies on normal and pathological conditions are now warranted to confirm our data. Another intriguing feature of DNA methylation in Arg/Arg and Arg/Pro carriers was its bimodal distribution. We were not able to correlate this feature with any of the clinic-biological annotations at our disposal. It is, thus, tempting to hypothesize that p53 impact on DNA methylation could be modulated by another genetic trait. It is, indeed, well known that DNA methylation levels in humans are strongly influenced by polymorphisms affecting genes controlling one-carbon metabolism $[59,60]$. Moreover other polymorphic effectors of DNA methylation, to be found in the oxidative stress pathway or among partners acting directly in DNA methylation (eg DNMTs), can be suspected to influence methylation levels [61-63].

Being aware that we do not provide a mechanistic explanation to our observations, some conspicuous differential expression affecting genes involved in DNA methylation metabolism, particularly those of DNMT3A (methylating) or $A P O B E C 3 B$ (demethylating), however, are in keeping with the current model of DNAmethylation metabolism [64]. It is well known that p53 entertains tight connections with the different cellular DNA-methyltransferases. Indeed, p53 and Dnmt3A are direct interactors as shown by co-immunoprecipitation experiments $[65,66]$. In addition, and in absence of mutagenic stress, p53 is known to directly inhibit DNMT1 expression by trapping $\mathrm{Sp} 1$ and repressive chromatin modifiers on the promoter of the gene $[67,68]$. The links between p53 and Dnmt1 are, however, far more complex. Both proteins have been shown to physically interact on various $\mathrm{p} 53$-responsive promoters (eg survivin/BIRC5) leading to their inactivation through DNA methylation as well as other chromatin modifications $[38,69]$. These data and the well-described differential activities of p53 Arg/Pro isoforms in other epigeneticsensitive phenomena such as cancer or ageing, make plausible a differential activity of rs1042522 on DNA methylation levels.

Finally, we showed a mild but significant increased ability to recover from decitabine treatment in Pro-carrying cells than in Arg carriers. This is in line with our hypothesis according to which tumorigenesis is less dependent on DNA methylation in Pro than in Arg carriers. In addition, and despite hitherto disappointing results in solid tumors, our data suggested that decitabine use in a codon 72 Arg/Arg wild-type TP53 context might significantly improve chemotherapeutic treatment $[70,71]$. The hypothesis obviously needs further confirmation but may be considered as a potential novel application in personalized treatment of cancer.

\section{Conclusion}

Our model of tumorigenesis, relying on TP53 Arg72Pro, may hold true only in selected populations of patients. In areas of high HCC incidence (Far East, Sub-Saharan Africa), populations are, indeed, exposed to potent risk factors such as perinatal infection with hepatitis B virus or exposure to aflatoxin B1. Such conditions, known to induce major genomic alterations in HCC, are presumably dwarfing the subtle impact of rs1042522 [72]. Cases of primary liver cancers with somatic changes depending primarily on TP53 R72P genotype might be confined to low incidence areas such as WNA, Middle East, Indian sub-continent or South America. In a research field dominated by clinical and biological studies undertaken on FarEastern patients, our work emphasizes the necessary space for a research conducted on alternative populations affected with specific tumor processes.Such studies may provide valuable information for the understanding of a disease which natural history and biology remain amazingly diverse from one world region to another.

\section{Material and methods \\ Tissue specimens and DNA extraction}

Sixty-three liver tissues including forty five HCC and seventeen matching corresponding non-tumorous liver tissues were obtained from WNA patients who underwent a liver surgery at University hospitals in Morocco $(\mathrm{n}=41)$ and Tunisia $(\mathrm{n}=4)$. Clinico-pathological features of patients are described in Table 1. In addition, PBMCs of thirty-five patients with chronic viral hepatitis $\mathrm{B}$ or $\mathrm{C}$ (27 $\mathrm{HBV}+$ and $8 \mathrm{HCV}+$ ) but without tumors were collected for comparative methylation analysis with 25 PBMCs samples from patients with HCCs. All samples have been already published in previous surveys [2]. The research was conducted with the informed consent of the patients in accordance to the recommendations issued by the conference of Helsinki. It was approved by the Ethics Committees of the Faculty of Medicine of Casablanca and that of the Tunisian Ministry of Health. DNA was extracted from frozen tissues and blood samples as previously described [73].

\section{SNP genotyping, Screening of mutations and LOH}

Data of SNP in TP53 (rs1042522) were previously published [74]. Exons 4-10 of TP53, exons 2-6 of CTNNB1, exons 2-8 of AXIN1 were analyzed for the presence of point mutations by PCR-sequencing as previously described (2). Six chromosomes (1p, 4q, 6q, 8p, 9p, 17p) considered as "hotspots" of deletions in $\mathrm{HCC}$, were 
tested for loss of heterozygosity (LOH) according to the protocol previously described [72].

\section{Sodium bisulfite treatement}

PBMCs, non-tumorous and tumorous genomic DNA samples were subjected to bisulfite treatment using Epitect $^{\circ}$ Bisulfite Kit (Qiagen, Courtabœuf, France) according to manufacturer's instructions. WI38 cells DNA were used as positive control of methylation after treatment with 12 units SssI methyltransferase (NE Biolabs, Ipswich, MA) in the presence of S-adenosyl-methionine $32 \mu \mathrm{M}$.

\section{Methylation assessment}

Methylation status was assessed for 10 loci including eight cancer-related genes and two miRNAs coding loci, methylation presence was determined by methyl-specific PCR (MSP) for RIZ1, RASSF1, SOCS1, TERT, TNFRSF10C and GSTP1 genes (Additional file 1: Table S4), and using COBRA for NRG1, CLU, mir-203 and mir-663 genes (Additional file 1: Table S5). Quantification of LINE-1 methylation was performed by COBRA as well according to the method described previously [75]. Variations in bands intensity were analyzed by densitometry using a CCD camera and the GeneTools software (Syngene, Ozyme, Saint-Quentin-en-Yvelines, France). A $50 \%$ increase of methylated product in tumorous DNA as compared with non-tumorous was considered as the positive threshold. The methylation index (MethIndex) was defined as the ratio of the number of loci found methylated $(\mathrm{Met}(+)$ Loci) on the total number of informative loci in a given sample $([\operatorname{Met}(+)+\operatorname{Met}(-)]$ Loci): $\operatorname{Met}(+)-\operatorname{Loci} \div[\operatorname{Met}(+)+\operatorname{Met}(-)] \operatorname{Loci}$.

\section{Methyl-specific PCR (MSP)}

Each PCR reaction was performed in a $25 \mu \mathrm{l}$ final volume containing 100 ng of genomic DNA, 1X PCR buffer, $1.5 \mathrm{mM} \mathrm{MgCl}$, $200 \mathrm{mMdNTP}, 20 \mathrm{pmol}$ of each primer, 5 units of AmpliTaq GOLD DNA polymerase (Applied Biosystem, Saint-Aubin, France). Reactions were subjected to $94^{\circ} \mathrm{C}$ for $5 \mathrm{~min}$, followed by 40 cycles at $95^{\circ} \mathrm{C}$ for $1 \mathrm{~min}, 50-60^{\circ} \mathrm{C}$ for $1 \mathrm{~min}$ and $72^{\circ} \mathrm{C}$ for $1 \mathrm{~min}$ and final extension at $72^{\circ} \mathrm{C}$ for $7 \mathrm{~min}$ on a MyCycler thermal cycler (Bio-Rad, Marnes-la-Coquette, France). PCR products were separated on 3\% agarose gels stained with ethidium bromide (Euromedex, Souffelweyersheim, France) as shown in Figure 1A [76-78]. All primer sequences are provided in Additional file 1: Table S4. Primers used for GSTP1, RASSF1, RIZ1, and hTERT analyses have been previously published [79-81].

\section{Combined bisulfite restriction assay (COBRA)}

PCR reactions were performed as described in MSP method with modification of Taq DNA polymerase using
Platinium ${ }^{\bullet}$ Taq DNA Polymerase (Life Technologies, Illkirch, France). A volume of $15 \mu \mathrm{l}$ of PCR products was then digested with suitable restriction enzymes (Fermentas, Life Technologies, Illkirch, France, Additional file 1: Table S5). PCR products were separated on $2.5 \%$ stained agarose gels and results were determined referring to the density of bands related to those of controls (Figure 1B). Primers used for miR-203 and LINE1 analyses have been previously published $[12,75]$.

\section{Cell cultures, western blot analysis, MTT assay}

HCC derived cell lines analyzed have been described previously [82] (Additional file 4). The cells were cultured in DMEM (Life Technologies, Saint-Aubin, France) supplemented with FBS (10\%, Biowest, Nuaille, France) and antibiotic-antimycotic. Cells were incubated and maintained at $37^{\circ} \mathrm{C}$ with humified air and $5 \%$ $\mathrm{CO}_{2}$ (Binder, Tuttlingen, Germany). Cells at 50-60\% confluence were treated for 6-96 h at various concentrations of doxorubicin (Selleck chemicals, Euromedex, Souffelweyersheim, France) and/or decitabine (Fluka, Saint-Quentin Fallavier, France). DNA, RNA, and proteins were extracted from 6-well plates (TPP, Dominique Dutscher, Brumath, France). Cell culture experiments were performed at least three times. For protein analysis, cells were washed in cold phosphate buffered saline (PBS), lysed in Laemmli buffer as described previously and samples loaded on Criterion XT precast gels (Bio-Rad, Marnes-la-Coquette, France) [83]. Western-blots were carried out with a Trans-blot Turbo transfer system as indicated by the manufacturer (Bio-Rad). Blots were probed with primary antibody against p53 (Santa-Cruz, CliniSciences, Nanterre, France sc-6243, 1/1000) and vinculin (Abcam, Cambridge, UK, ab18058, 1/500) or actin (Sigma, Saint-Quentin Fallavier, France, a2066, 1/ 5000). Cell viability was measured by MTT (3-(4,5-dimethylthiazol-2-yl)-2,5-diphenyl-tetrazolium bromide, Euromedex) assay after seeding in flat bottom 96-well plates (TPP) and treatment for various time length. Formazan crystal resulting from MTT reduction was solubilized in acid isopropanol and absorbance measured at $570 \mathrm{~nm}$ on a Fluostar Omega plate reader (BMG Labtech, Champigny/Marne, France).

\section{Quantitative RT-PCR}

Total RNA was obtained from cell culture by direct lysis in Tri-Reagent (Sigma). One microgram of RNA was reverse transcribed using a high-capacity cDNA Archive Kit (Applied Biosystems, Villebon, France) according to the manufacturer's specifications. Expression of 15 genes involved in DNA methylation (DNMT3A-B-L, DNMT1) and demethylation (TET1-3, APOBEC1, APOBEC3A-B-C$H, A I D, S M U G$ and TDG) processes was analyzed. Two known p53-responsive genes (p21-CDKN1A, GADD45) 
were included in the analysis. Real-time PCR was performed in a CFX96 qPCR machine (Bio-Rad). All samples were measured in triplicate. The PCR volume of $10 \mu \mathrm{l}$ included $20 \mathrm{ng}$ of RT product, $1 \times$ TaqMan Universal PCR master mix and $1 \mu \mathrm{l}$ of pre-validated Taqman Gene Expression Assay (TaqMan FG Shelf, Applied Biosystems, see Additional file 1: Table S6). The reactions were incubated in a 96-well optical plate at $95^{\circ} \mathrm{C}$ for $10 \mathrm{~min}$, followed by 40 cycles of $95^{\circ} \mathrm{C}$ for $15 \mathrm{sec}$ and $60^{\circ}$ for $1 \mathrm{~min}$. The Ct data was determinate using default threshold settings. The threshold cycle $(\mathrm{Ct})$ is defined as the fractional cycle number at which the fluorescence passes the fixed threshold. For data analysis, gene expression values were determined using the calculation of the relative quantitation (RQ) of target genes normalized to a calibrator corresponding to 5 normal livers. RQ calculation was performed using the DeltaCT method with the geometric mean of three reference genes (TRIM44, Hs00214040_m1, HMBS; Hs00609297_m1 and LMF2; Hs00611068_m1) as reference [84]. The three references genes were selected among 12 constant genes arising from a previous array analysis of $70 \mathrm{HCC}$ samples and 9 normal livers to which were applied algorithms described previously [85].

\section{Quantitative real-time PCR on genomic DNA}

QPCR coupled Methyl Sensitive Restriction Enzyme (MSRE) reactions were carried out as described by Melnikof et al. [37]. Genomic DNA was extracted as described previously and quantified using NanoDrop ND-1000 (NanoDrop, Wilmington, USA) [82]. All digestions were performed with HpaII, a methylation sensitive restriction enzyme. An amount of $200 \mathrm{ng}$ of genomic DNA was digested $16 \mathrm{~h}$ at $37^{\circ} \mathrm{C}$ in a final volume of $100 \mu \mathrm{l}$ containing 10 units of HpaII or HhaI. After incubation, each digested sample was diluted 5fold with sterile water and incubated at $65^{\circ} \mathrm{C}$ for $15 \mathrm{~min}$ to inactivate the enzyme. QPCR was performed in triplicate on a Bio-Rad CFX-96 system (Bio-Rad) with $10 \mu \mathrm{l}$ of reaction mixture containing $4 \mathrm{ng}$ of digested DNA, $5 \mu \mathrm{l}$ of $2 \mathrm{X}$ Sso Advanced SYBR Green Supermix (Bio$\mathrm{Rad})$ and 5 pmoles of each primer. Primers at CMYA5 gene, mapping in 5q21.1, a region non-affected by copy number changes in HCC, were used as reference. QPCR conditions included a denaturation step at $98^{\circ} \mathrm{C}$ for $2 \mathrm{~min}$ followed by 40 cycles at $98^{\circ} \mathrm{C}$ for $5 \mathrm{sec}$ and $60^{\circ} \mathrm{C}$ for $1 \mathrm{~min}$ [86]. Results were analyzed using the CFX Manager and Precision Melt Analysis software (Bio-Rad). Primers are provided on Additional file 1: Table S7.

\section{Statistical analysis}

Instat software (GraphPad Software Inc, La Jolla, CA, USA) was used for statistical analysis of the data with the Chi-square test, Fisher's exact test, Student's $t$-test, the
Mann-Whitney test, ANOVA test and Kruskal-Wallis test as appropriate. The cut-off value for significance was of $\mathrm{P}<0.05$. All tests were two-sided.

\section{Additional files}

\begin{abstract}
Additional file 1: Table S1. Functions of the genes investigated for DNA methylations in HCC from Western North-African patients. Table S2. Correlation matrix of the methylated loci as detected in North-African Hepatocellular Carcinoma. Table S3. Genetic features associated with abnormal DNA methylation in North-African Hepatocellular Carcinoma. Table S4. Methylation-specific PCR primers. Genome locations of primer sequences are given according to those provided by the Genome browser gateway. (http://genome-euro.ucsc.edu/cgi-bin/hgGateway? $\mathrm{db}=$ hg 11 \&redirect=auto\&source=genome.ucsc.edu). Um: amplifies unmethylated DNA, M: amplifies methylated DNA. Table S5. COBRA assay primers. Genome locations of primer sequences are given according to those provided by the Genome browser gateway. (http://genome-euro. ucsc.edu/cgi-bin/hgGateway?db=hg 11\&redirect=auto\&source=genome. ucsc.edu). Table S6. Taqman Gene Expression Assay (PE Applied Biosystems). Table S7. MSRE-qPCR primers. Genome locations of primer sequences are given according to those provided by the Genome browser gateway (http://genome-euro.ucsc.edu/cgi-bin/hgGateway?db=hg11\& redirect=auto\&source=genome.ucsc.edu).
\end{abstract}

Additional file 2: Figure S1. (A) DNA methylation levels for the loci studied. No difference was statistically significant. (B) Methylation Index at 9 loci for DNA extracted from peripheral lymphocytes in patients with or without primary liver cancer. (C) Non-supervised hierarchical clustering of DNA methylation in PBMCs does not detect any difference between patients with or without liver cancer.

Additional file 3: Figure S2. Map of six among the seven promoters analyzed by MSRE-qPCR. Positions of primers are indicated by double arrows. Nucleotide position of primers is defined according to transcription Start site $(\triangleright 1)$. Restriction sites are shown above the gene. Exons are symbolized at the scale by rectangles. BIRC5 assay is not shown.

Additional file 4: Supplementary data.

\section{Abbreviations}

ANOVA: Analysis of variance; APOBEC: Apolipoprotein mRNA editing enzyme; Arg: Arginine; CIN: Chromosomal instability; CLU: Clusterin; COBRA: Combined bisulfite restriction assay; CTNNB1: Beta-catenin; DNMT: DNA methyltransferase; GSTP1: Glutathione S-transferase pi 1; HBV: Hepatitis B virus; HCC: Hepatocellular carcinoma; HCV: Hepatitis C virus; LINE-1: Long interspersed nuclear element 1; LOH: Loss of heterozygosity; mir: microRNA; MSP: Methyl-specific PCR; NRG1: Neuregulin1; NTL: Non-tumorous liver; PBMCs: Peripheral blood mononuclear cells; Pro: Proline; SOCS1: Suppressor of cytokine signaling 1: TET: Tet methylcytosinedioxygenase; TP53: Tumor protein 53; TSG: Tumor suppressor gene; R72P: Arginine72Proline; RASSF1: Ras association domain family member 1; RIZ1: Retinoblastoma-interacting zinc-finger protein 1; SNP: Single nucleotide polymorphism; WNA: Western North-Africa.

\section{Competing interests}

The authors declare that they have no competing interests.

\section{Authors' contributions}

AM and PP designed research. KR and AM performed the molecular genetics study. PP performed cell culture experiments. KR, AM, SE, RA, OB, HT, MK, AE, $A D, S B$ and PP analyzed the data. KR and PP wrote the manuscript. All authors read and approved the final manuscript.

\section{Acknowledgements}

This work was funded by the French Ligue Nationale Contre le Cancer (LNCC) Odyssey-RE and the Pasteur Institutes International Network (RIIP).We are grateful to Eliane Coeffier, Marc Jouan and Jérôme Salomon from the Division International of the Institut Pasteur for their support. We thank Hélène Bierne, Marie-Louise Michel and Ophélie Godon for their scientific suggestions. 


\section{Author details}

'Unité d'Organisation Nucléaire et Oncogenèse, INSERM U993, Institut Pasteur, 28 rue du Docteur Roux, F-75724 Paris, Cedex 15, France. 2Laboratoire des Hépatites Virales, Institut Pasteur du Maroc, 1 Place Louis Pasteur, 20360 Casablanca, Morocco. ${ }^{3}$ Service de Médecine C-Gastroentérologie, CHU Ibn-Sina, Rabat, Morocco. ${ }^{4}$ Equipe d'Anthropogénétique et de Biotechnologies, Faculté des Sciences Chouaib Doukkali, El Jadida, Morocco. ${ }^{5}$ Laboratoire de Virologie Clinique, Institut Pasteur de Tunis, Tunis, Tunisie.

\section{Received: 10 July 2014 Accepted: 11 March 2015}

Published online: 02 April 2015

\section{References}

1. Ferenci P, Fried M, Labrecque D, Bruix J, Sherman M, Omata M, et al. World Gastroenterology Organisation Guideline. Hepatocellular carcinoma (HCC): a global perspective. J Gastrointestin Liver Dis. 2010;19:311-7.

2. Pineau P, Ezzikouri S, Marchio A, Benazzouz M, Cordina E, Afifi R, et al. Genomic stability prevails in North-African hepatocellular carcinomas. Dig Liv Disease. 2007:39:671-7.

3. Bahri O, Ezzikouri S, Alaya-Bouafif NB, Iguer F, Feydi AE, Mestiri $H$, et al. First multicenter study for risk factors for hepatocellular carcinoma development in North Africa. World J Hepatol. 2011;27:24-30.

4. Bruix J, Boix L, Sala M, Llovet JM. Focus on hepatocellular carcinoma. Cancer Cell. 2004:5:215-9.

5. Laurent-Puig P, Zucman-Rossi J. Genetics of hepatocellular tumors. Oncogene. 2006;25:3778-86.

6. Suriawinata A, Thung SN. Molecular signature of early hepatocellular carcinoma. Oncology. 2010;78:36-9.

7. Zucman-Rossi J. Molecular classification of hepatocellular carcinoma. Dig Liver Dis. 2010;42:235-41.

8. Lee J, Heo J, Libbrecht L, Chu IS, Kaposi-Novak P, Calvisi DF, et al. A novel prognostic subtype of human hepatocellular carcinoma derived from hepatic progenitor cells. Nat Med. 2006;12:410-6.

9. Boyault S, Rickman DS, de Reyniès A, Balabaud C, Rebouissou S, Jeannot E, et al. Transcriptome Classification of HCC Is Related to Gene Alterations and to New Therapeutic Targets. Hepatology. 2007:45:42-52.

10. Tischoff I, Tannapfel A. DNA methylation in hepatocellular carcinoma. World J Gastroenterol. 2008;14:1741-8.

11. Moribe T, lizuka N, Miura T, Kimura N, Tamatsukuri S, Ishitsuka H, et al. Methylation of multiple genes as molecular markers for diagnosis of a small, well-differentiated hepatocellular carcinoma. Int J Cancer. 2009;125:388-97.

12. Furuta M, Kozaki Kl, Tanaka S, Arii S, Imoto I, Inazawa J. miR-124 and miR-203 are epigenetically silenced tumor-suppressive microRNAs in hepatocellular carcinoma. Carcinogenesis. 2010:31:766-76.

13. Potapova A, Albat C, Hasemeier B, Haeussler K, Lamprecht S, Suerbaum S, et al. Systematic cross-validation of 454 sequencing and pyrosequencing for the exact quantification of DNA methylation patterns with single CpG resolution. BMC Biotechnol. 2011:11:6-15.

14. Kim Y, Lee HS. Single nucleotide polymorphisms associated with hepatocellular carcinoma in patients with chronic hepatitis B virus infection. Intervirology. 2005;48:10-5.

15. Jin F, Xiong WJ, Jing JC, Feng Z, Qu LS, Shen XZ. Evaluation of the association studies of single nucleotide polymorphisms and hepatocellular carcinoma: a systematic review. J Cancer Res Clin Oncol. 2011;137:1095-104.

16. Hu S, Zhao L, Yang J, Hu M. The association between polymorphism of P53 Codon72 Arg/Pro and hepatocellular carcinoma susceptibility: evidence from a meta-analysis of 15 studies with 3,704 cases. Tumour Biol. 2014;35:3647-56.

17. Soussi T, Wiman KG. Shaping genetic alterations in human cancer: The p53 Mutation Paradigm. Cancer Cell. 2007;12:303-12.

18. Nomoto S, Kinoshita T, Kato K, Otani S, Kasuya H, Takeda S, et al. Hypermethylation of multiple genes as clonal markers in multicentric hepatocellular carcinoma. Br J Cancer. 2007:97:1260-5.

19. Nishida N, Nagasaka T, Nishimura T, Ikai I, Boland CR, Goel A. Aberrant methylation of multiple tumor suppressor genes in aging liver, chronic hepatitis, and hepatocellular carcinoma. Hepatology. 2008;47:908-18.

20. Rauhala HE, Porkka KP, Saramäki OR, Tammela TL, Visakorpi T. Clusterin is epigenetically regulated in prostate cancer. Int J Cancer. 2008;123:1601-9.
21. Niopoulos D, Satra M, Drakaki A, Poultsides GA, Tsezou A. Epigenetic regulation of hTERT promoter in hepatocellular carcinomas. Int J Oncol. 2009;34:391-9.

22. Herath NI, Purdie DM, Kew MC, Smith JL, Young J, Leggett BA, et al. Varying etiologies lead to different molecular changes in Australian and South African hepatocellular carcinomas. Int J Oncol. 2009:35:1081-9.

23. Formeister EJ, Tsuchiya M, Fujii H, Shpyleva S, Pogribny IP, Rusyn I. Comparative analysis of promoter methylation and gene expression endpoints between tumorous and non-tumorous tissues from HCV-positive patients with hepatocellular carcinoma. Mutat Res. 2010;692:26-33.

24. Lambert MP, Paliwal A, Vaissière T, Chemin I, Zoulim F, Tommasino M, et al. Aberrant DNA methylation distinguishes hepatocellular carcinoma associated with HBV and HCV infection and alcohol intake. J Hepatol. 2011:54:705-15.

25. Oster B, Thorsen K, Lamy P, Wojdacz TK, Hansen LL, Birkenkamp-Demtröder $\mathrm{K}$, et al. Identification and validation of highly frequent $\mathrm{CpG}$ island hypermethylation in colorectal adenomas and carcinomas. Int J Cancer. 2011;129:2855-66

26. Nishida N, Kudo M, Nagasaka T, Ikai I, Goel A. Characteristic patterns of altered DNA methylation predict emergence of human hepatocellular carcinoma. Hepatology. 2012;56:994-1003.

27. Jain S, Xie L, Boldbaatar B, Lin SY, Hamilton JP, Meltzer SJ, et al. Differential methylation of the promoter and first exon of the RASSF1A gene in hepatocarcinogenesis. Hepatol Res. 2014; doi: 10.1111/hepr.12449.

28. Kuo CC, Lin CY, Shih YL, Hsieh CB, Lin PY, Guan SB, et al. Frequent methylation of HOXA9 gene in tumor tissues and plasma samples from human hepatocellular carcinomas. Clin Chem Lab Med. 2014:52:1235-45.

29. Michailidi C, Soudry E, Brait M, Maldonado L, Jaffe A, lli-Gangas C, et al. Genome-wide and gene-specific epigenomic platforms for hepatocellular carcinoma biomarker development trials. Gastroenterol Res Pract. 2014;2014:597164

30. Ezzikouri S, El Feydi AE, Afifi R, El Kihal L, Benazzouz M, Hassar M, et al. MDM2 SNP309T>G polymorphism and risk of hepatocellular carcinoma: a case-control analysis in a Moroccan population. Cancer Detect Prev. 2009:32:380-5

31. Vogelstein B, Fearon E, Kern S, Hamilton S, Preisenger AC, Nakamura Y, et al. Allelotype of colorectal carcinomas. Science. 1989;244:207-11.

32. Nyce J. Drug-induced DNA, hypermethylation and drug resistance in human tumors. Cancer Res. 1989:49:5829-36.

33. Beckerman R, Prives C. Transcriptional Regulation by P53. Cold Spring Harb Perspect Biol. 2010;2:a000935.

34. Jeong B, Hu W, Belyi V, Rabadan R, Levine AJ. Differential levels of transcription of p53-regulated genes by the arginine/proline polymorphism: p53 with arginine at codon 72 favors apoptosis. FASEB J. 2010:24:1347-53.

35. Bhutani N, Burns DM, Blau HM. DNA demethylation dynamics. Cell. 2011;146:866-72

36. Thomas M, Kalita A, Labrecque S, Pim D, Banks L, Matlashewski G. Two polymorphic variants of wild-type p53 differ biochemically and biologically. Mol Cell Biol. 1999;19:1092-100

37. Melnikov A, Gartenhaus RB, Levenson AS, Motchoulskaia NA, Levenson Chernokhvostov W. MSRE-PCR for analysis of gene-specific DNA methylation. Nucleic Acids Res. 2005:33:e93.

38. Estève $P$, Chin HG, Pradhan S. Human maintenance DNA (cytosine-5)methyltransferase and p53 modulate expression of p53-repressed promoters. Proc Natl Acad Sci U S A. 2005;102:1000-5.

39. Ezzikouri S, Pineau P, Benjelloun S. Hepatitis B virus in the Maghreb region: from epidemiology to prospective research. Liver Int. 2013;33:811-9.

40. Ezzikouri S, Pineau P, Benjelloun S. Hepatitis $C$ virus infection in the Maghreb region. J Med Virol. 2013:85:1542-9.

41. el Tazi M, Essadi I, M'rabti H, Touyar A, Errihani PH. Systemic treatment and targeted therapy in patients with advanced hepatocellular carcinoma. N Am J Med Sci. 2011;3:167-75

42. Cherradi Y, Afifi R, Benbrahim H, Essamri W, Benelbarhdadi I, Ajana FZ, et al. Predictors of developing hepatocellular carcinoma in treated HCV-carriers in Morocco according to University Hospital experience. ISRN Hepatology. 2013. Article ID 438306: doi:10.1155/2013/438306.

43. Hernandez-Vargas H, Lambert MP, Le Calvez-Kelm F, Gouysse G, McKay-Chopin S, Tavtigian SV, et al. Hepatocellular carcinoma displays distinct DNA methylation signatures with potential as clinical predictors. PLOS One. 2010:5:e9749. 
44. Shen L, Kondo Y, Rosner G, Xiao L, Hernandez N, Vilaythong J, et al. MGMT promoter methylation and field defect in sporadic colorectal cancer. J Natl Cancer Inst. 2005;97:1330-8.

45. Ushijima T. Epigenetic field for cancerization. J Biochem Mol Biol. 2007:40:142-50.

46. Lou C, Du Z, Yang B, Gao Y, Wang Y, Fang S. Aberrant DNA methylation profile of hepatocellular carcinoma and surgically resected margin. Cancer Sci. 2009;100:996-1004.

47. Nishida N, Nishimura T, Nagasaka T, Ikai I, Goel A, Boland CR. Extensive methylation is associated with beta-catenin mutations in hepatocellular carcinoma: evidence for two distinct pathways of human hepatocarcinogenesis. Cancer Res. 2007;67:4586-94.

48. Hanel W, Moll UM. Links between mutant p53 and genomic instability. J Cell Biochem. 2012;113:433-9.

49. Nasr A, Nutini M, Palombo B, Guerra E, Alberti S. Mutations of TP53 induce loss of DNA methylation and amplification of the TROP1 gene. Oncogene. 2003;22:1668-77.

50. Dumont P, Leu Jl, Della Pietra AC, George DL, Murphy M. The Codon 72 polymorphic variants of p53 have markedly different apoptotic potential. Nat Genet. 2003;33:357-65.

51. Zhu Z, Cong WM, Liu SF, Dong H, Zhu GS, Wu MC. Homozygosity for Pro of p53 Arg72Pro as a potential risk factor for hepatocellular carcinoma in Chinese population. World J Gastroenterol. 2005;11:289-92.

52. Levine A, Tomasini R, McKeon FD, Mak TW, Melino G. The p53 family: guardians of maternal reproduction. Nat Rev Mol Cell Biol. 2011;12:259-65.

53. Richardson B. Impact of aging on DNA methylation. Ageing Res Rev. 2003:2:245-61.

54. Tyner S, Venkatachalam S, Choi J, Jones S, Ghebranious N, Igelmann H, et al. P53 mutant mice that display early ageing-associated phenotypes. Nature. 2002:415:45-53.

55. Ørsted D, Bojesen SE, Tybjaerg-Hansen A, Nordestgaard BG. Tumor suppressor p53 Arg72Pro polymorphism and longevity, cancer survival, and risk of cancer in the general population. J Exp Med. 2007;204:1295-301.

56. Lo HW, Stephenson L, Cao X, Milas M, Pollock R, Ali-Osman F. Identification and functional characterization of the human glutathione S-transferase P1 gene as a novel transcriptional target of the p53 tumor suppressor gene. Mol Cancer Res. 2008;6:843-50.

57. Calabrese V, Mallette FA, Deschênes-Simard X, Ramanathan S, Gagnon J, Moores A, et al. SOCS1 links cytokine signaling to p53 and senescence. Mol Cell. 2009;36:754-67.

58. Tian Y, Hou Y, Zhou X, Cheng H, Zhou R. Tumor suppressor RASSF1A promoter: p53 binding and methylation. PLoS One. 2011;6:e17017.

59. Xu X, Chen J. One-carbon metabolism and breast cancer: an epidemiological perspective. J Genet Genomics. 2009;36:203-14.

60. Coppedè F. Epigenetic biomarkers of colorectal cancer: Focus on DNA methylation. Cancer Lett. 2014;342:238-47.

61. Kojima C, Ramirez D, Tokar E, Himeno S, Drobná Z, Stýblo M, et al. Requirement of arsenic biomethylation for oxidative DNA damage. J Natl Cancer Inst. 2009;101:1670-81.

62. Chun J, Bae J, Park T, Kim J, Park B, Cheong H, et al. Putative association of DNA methyltransferase 1 (DNMT1) polymorphisms with clearance of HBV infection. BMB Rep. 2009;42:834-9.

63. Zhao C, Yan F, Wu H, Qiao F, Qiu X, Fan H. DNMT3A-448A > G polymorphism and the risk for hepatocellular carcinoma. Biomed Rep. 2013;1:664-8.

64. Bhutani N, Brady JJ, Damian M, Sacco A, Corbel SY, Blau HM. Reprogramming towards pluripotency requires AID-dependent DNA demethylation. Nature. 2010:463:1042-7.

65. Wang Y, Kamarova Y, Shen KC, Jiang Z, Hahn MJ, Wang Y, et al. DNA methyltransferase-3a interacts with p53 and represses p53-mediated gene expression. Cancer Biol Ther. 2005;4:1138-43.

66. Hervouet E, Vallette FM, Cartron PF. Dnmt3/transcription factor interactions as crucial players in targeted DNA methylation. Epigenetics. 2009:4:487-99.

67. Lin R, Wu C, Chang J, Juan L, Hsu H, Chen C, et al. Dysregulation of p53/Sp1 control leads to DNA methyltransferase-1 overexpression in lung cancer. Cancer Res. 2010;70:5807-17.

68. Peterson E, Bögler O, Taylor S. p53-mediated repression of DNA methyltransferase 1 expression by specific DNA binding. Cancer Res. 2003;63:6579-82.

69. Le Gac G, Estève PO, Ferec C, Pradhan S. DNA damage-induced down-regulation of human $\mathrm{Cdc} 25 \mathrm{C}$ and $\mathrm{Cdc} 2$ is mediated by cooperation between p53 and maintenance DNA (cytosine-5) methyltransferase 1. J Biol Chem. 2006;281:24161-70.

70. Cowan L, Talwar S, Yang AS. Will DNA methylation inhibitors work in solid tumors? A review of the clinical experience with azacitidine and decitabine in solid tumors. Epigenomics. 2010;2:71-86.

71. Boumber Y, Issa JP. Epigenetics in cancer: what's the future? Oncology (Williston Park). 2011;25:220-6. 228.

72. Pineau P, Marchio A, Battiston C, Cordina E, Russo A, Terris B, et al. Chromosome instability in human hepatocellular carcinoma depends on p53 status and aflatoxin exposure. Mutat Res. 2008;653:6-13.

73. Pineau P, Nagai H, Prigent S, Wei Y, Gyapay G, Weissenbach J, et al. Identification of three distinct regions of allelic deletions on the short arm of chromosome 8 in hepatocellular carcinoma. Oncogene. 1999;18:3127-34.

74. Ezzikouri S, El Feydi AE, Chafik A, Benazzouz M, El Kihal L, Afifi R, et al. The Pro variant of the p53 codon 72 polymorphism is associated with hepatocellular carcinoma in Moroccan population. Hepatol Res. 2007;37:748-54.

75. Yang A, Estécio MR, Doshi K, Kondo Y, Tajara EH, Issa JP. A simple method for estimating global DNA methylation using bisulfite PCR of repetitive DNA elements. Nucleic Acids Res. 2004;32:e38.

76. Du Y, Carling T, Fang W, Piao Z, Sheu JC, Huang S. Hypermethylation in human cancers of the RIZ1 tumor suppressor gene, a member of a histone/ protein methyltransferase superfamily. Cancer Res. 2001;61:8094-9.

77. Lo KW, Kwong J, Hui AB, Chan SY, To KF, Chan AS, et al. High frequency of promoter hypermethylation of RASSF1A in nasopharyngeal carcinoma. Cancer Res. 2001;61:3877-81.

78. Kumari A, Srinivasan R, Vasishta RK, Wig JD. Positive regulation of human telomerase reverse transcriptase gene expression and telomerase activity by DNA methylation in pancreatic cancer. Ann Surg Oncol. 2009;16:1051-9.

79. Yoshikawa H, Matsubara K, Qian GS, Jackson P, Groopman JD, Manning JE, et al. SOCS-1, a negative regulator of the JAK/STAT pathway, is silenced by methylation in human hepatocellular carcinoma and shows growthsuppression activity. Nat Genet. 2001;28:29-35.

80. House M, Guo M, lacobuzio-Donahue C, Herman J. Molecular progression of promoter methylation in intraductal papillary mucinous neoplasms (IPMN) of the pancreas. Carcinogenesis. 2003;24:193-8

81. Sunami E, Shinozaki M, Higano CS, Wollman R, Dorff TB, Tucker SJ, et al. Multimarker circulating DNA assay for assessing blood of prostate cancer patients. Clin Chem. 2009;55:559-67.

82. Pineau P, Marchio A, Nagamori S, Seki S, Tiollais P, Dejean A. Homozygous Deletion scanning in Hepatobiliary Tumor Cell Lines reveals Alternative Pathways for Liver Carcinogenesis. Hepatology. 2003;37:852-61.

83. Seeler J, Marchio A, Losson R, Desterro JM, Hay RT, Chambon P, et al. Common properties of nuclear body protein SP100 and TIF1alpha chromatin factor: role of SUMO modification. Mol Cell Biol. 2001;21:3314-24.

84. Pineau P, Volinia S, McJunkin K, Marchio A, Battiston C, Terris B, et al. MiR-221 Overexpression contributes to liver tumorigenesis. Proc Natl Acad Sci U S A. 2010;107:264-9.

85. Vandesompele J, De Preter K, Pattyn F, Poppe B, Van Roy N, De Paepe A, et al. Accurate normalization of real-time quantitative RT-PCR data by geometric averaging of multiple internal control genes. Genome Biol. 2002;3:34.

86. Hua D, Hu Y, Wu YY, Cheng ZH, Yu J, Du X, et al. Quantitative methylation analysis of multiple genes using methylation-sensitive restriction enzyme-based quantitative PCR for the detection of hepatocellular carcinoma. Exp Mol Pathol. 2011;91:455-60. 